kyse pikemminkin kuvausten ja analyysien todellistamisesta, todellisuuden mukaisuudesta kuin yleistettävyydestä.

Aineistosta käy ilmi, että monen rehtorin identiteetin taustalla on opettajuus. Niinpä useassa tapauksessa havaitaan, että rehtorin toimintaorientaatio heiluu opettajuuden ja johtajuuden välillä. Konkreettisessa johtamistyössä tämä asetelma ei ole helppo, koska rehtorilta edellytetään kykyä irrottautua opettajuudesta. Hänen on kyettävä katsomaan sosiaalista tilaansa oman tehtävänsä, johtajuuden, kautta.

Tutkija esittää johtamisen tutkimukselle uuden haasteen: johtamistutkimusta dominoivalle liikkeenjohdolliselle paradigmalle tulee etsiä oppilaitoksiin sopivaa vaihtoehtoista näkökulmaa, jossa vuorovaikutuksellisuus ja oppilaitosten toimintaympäristön erityisyydet voidaan ottaa paremmin huomioon. Liikkeenjohdollinen johtajuusorientaatio ei Ahosen mukaan oikein istu oppilaitosjohtamiseen. Tämä väitöskirja on mielestäni lupaava tutkimus avaamaan toista näkökulmaa, joka liikkeenjohdon paradigmaa täydemmin voi tuottaa arjen johtajuuden tukea ja toimintaympäristön analyysia. Sosiaalisen tilan analysointi voi olla hedelmällinen väline myös oppilaitosjohtajuuden kehittämiseen.

\section{Aki Ojakangas}

\title{
Kolmas ikä elämän parasta aikaa?
}

Ilka Haarni (2010). Kolmas elämä. Aktiiviset eläkeläiset kaupungissa. Gaudeamus.

$\mathrm{K}_{\mathrm{o}}$ nyt osana Ikainstituutissa toteunyt osana Ikäinstituutissa toteutettua ikäihmisten vapaaehtoistoiminnan tutkimushanketta Vastavuoroisuus, vertaisuus, osallisuus (Vavero). Raha-automaattiyhdistyksen rahoittamassa hankkeessa Haarni tutki eläkeikäisten osallistumista vapaaehtoistoimintaan kyselyn ja etnografisen tutkimusmetodin avulla.

Toteutus oli 12000 asukkaan pääkaupunkiseudun lähiössä, jonka Haarni nimesi "Lähiläksi”". Lähiö on itsessään kuin pieni kaupunki: siellä ovat tarjolla kaikki palvelut.

Kolmannella elämällä Haarni tarkoittaa työiän ja varsinaisen vanhuuden väliin sijoittuvaa elämänvaihetta, jonka tutkija Peter Laslett kuvaa "vapauksien elämänvaiheena". Ominaisuutena on suhteellisen hyvä terveys ja toimintakykyisyys, kun vanhuus on laslettilaisin määrityksin hoivaa edellyttävä vaihe, ensin neljäs ja sitten jo pyörätuolissa tai sängyn pohjalla viides ikä. Joku Haarnin 22 haastatellusta luonnehtikin kolmatta ikää elämän parhaaksi ajaksi.

\section{Organisoitu toiminta kriteerinä}

Haarni on rajannut tutkimuksensa eläkeikäisiin, jotka osallistuvat eriasteisesti organisoituun toimintaan. Sellaisia hän on luokitellut neljä perustyyppiä: yhdistystoiminnan, harrastamisen, vapaaehtoistyön ja omaehtoisen kokoontumisen.

Kun Seppo Niemelä luotsasi oikeusministeriössä hallituksen demokratian ja kansalaisaktiivisuuden politiikkaohjelmaa, rajat olivat tiukemmat. Kansalaisaktiivisuus määrittyi järjestötoiminnassa luottamustehtäviin, sen sijaan tapahtumiin tai toimintaan osallistuminen ei ollut riittävä kriteeri.

Haarni myöntää kirjassaan, että aktiivisuudella ja osallistumisella voidaan ymmärtää kovin monenasteista vireyttä. Haastateltava ja haastattelija voivat ymmärtää sanat eri tavalla. Aktiivisuus onkin veteen piirretty viiva. Tutkimuksen ulkopuolella on nimittäin kaikki se aktiivisuus, joka kohdistuu esimerkiksi kanssakäymiseen sukulaisten kanssa, lastenlapsista huolehtiminen, omaehtoinen harrastaminen kuten lukeminen ja kättentaitojen ylläpito tai ei-organisoitu liikunta ja ulkoilu.

Organisoidun toiminnan ulkopuolella oleviakin on paljon, heitä jotka viihtyvät yksityisyydessään, pitävät kotona ja kesämökillä puuhastelusta, marjastamisesta tai ystävien kanssa kanssakäymisestä. Missä siis on toimeliaisuuden ja toimettomuuden raja? Terveyden vuoksi estyneitä ja yksinäisyydestä kärsiviä lienee heitäkin.

Tai mikä on toimeliaisuuden intensiteetin merkitys: mukana jossakin kerran viikossa vai joka päivä jossakin?

Ilka Haarni seurasi eläkeikäisten toimintaa menemällä heidän 
kerhotoimintaansa mukaan. Kohteiksi hän valitsi pari poliittistaustaista eläkeläisjärjestöä sekä koko joukon erilaisia Lähilässä toimivia järjestöjä, joihin osallistuu ainoastaan eläkeikäisiä. Vaikka kolmannen iän ihmiset ovat aktiivisia, moni järjestöistä potee pulaa puurtavista vastuunkantajista. Nuorempia sitoutujia ei tahdo löytyä tilalle, tapahtumiin ja toimintaan osallistujia kylläkin. “... Ne vetäjät on samanlaisia, nekin alkaa olemaan tällaisii perkeleen ikäloppuja", tuskailee nuorempien viitsimättömyyttä mies, $60 \mathrm{v}$.

\section{Yksilöllisesti \\ samanlaisia}

Haarnin tulokset eivät yllätä. Kolmannen iän ihmiset ovat aktiivisia ja toimivia, vaikka sitoutumisen asteessa on suuria eroja. Joku osallistuu tilaisuuksiin, kun joku toinen organisoi niitä, hoitaa talkoohengessä jonkin tapahtumaan liittyvän työtehtävän tai on luottamustehtävissä.

Toimimisen ja harrastamisen kirjoja tuntuu olevan yhtä paljon kuin eläkeläisiäkin. Siinä missä toiset keskittävät aktiivisuutensa yhteen heille tärkeään yhdistykseen ja ovat mukana yhdistyksen kaikissa erityyppisissä toiminnoissa, toisilla on useita yhdistyksiä ja he sukkuloivat niissä, tekevät yhdessä yhdistyksessä yhtä ja toisessa toista.

Kiinnostuksen kohteet ovat erilaiset. Yhteistä on aktiivisuus, sosiaalisuus ja yhdessä viihtyminen. Ollaan samanlaisia yksilöllisesti. Kerhotuttavuuksia, läheisiäkään, ei uloteta toiminnon ulkopuolelle yhteistä kotimatkaa lukuun ottamatta. Yksityisyyteen kuuluvat eri ihmiset.

Haastateltavien ammatti- ja koulutustausta oli kirjava. Haar- nin päätelmä tuntuu kuitenkin olevan se, että yhdessäoleminen ja -tekeminen yhdistävät ja luokkarajat menettävät merkityksensä. Sen sijaan kirjoittaja toteaa, ettei pysty tutkimuksensa perusteella arvioimaan osallistumattomien ihmisten luokkasidonnaisuutta.

Mielenkiintoinen havainto on se, että kolmatta ikää elävät eivät juuri kohtaa työikäisiä. Heidän päivärytminsä on tyystin erilainen. He näkevät äitiyslomalla olevia nuoria naisia tai työttömiä, mutta he asioivat kaupoissa ja liikkuvat julkisissa liikennevälineissä silloin, kun työikäiset ovat työssä. Haarni koki tämän omakohtaisesti heittäytymällä usean kuukauden ajaksi tutkittaviensa elämään. Hän kadotti kontaktin työikäisten elämään.

\section{Elinikäinen oppiminen tutkijapuhetta}

Kolmannen iän väki opiskelee totta kai. Mutta eivät he kansalaisopistossa opiskeluaan aina opiskeluksi nimeä, vielä vähemmän elinikäiseksi oppimiseksi. Sen sijaan he kokevat ylläpitävänsä elämänlaatua sekä kehittävänsä ja toteuttavansa itseään.
Erilaiset toimimisen motiivit ovat moninaisin sekoituksin läsnä: terveyden ylläpito, hyvinvoinnista huolehtiminen, yhteisön ja yhdessäolon tärkeys, ajankulu, arjen poljennon hakeminen, oleminen hyödyksi ja avuksi muille tai omalle yhdistykselle, kehittyminen ja itseilmaisu. Jokin orientaatio voi olla ensisijainen, mutta useimmilla mukana on monta motiivia.

Paikalle ei tulla purkamaan mielipahaa, pätemään tai kyräilemään. Seurallisuuteen kuuluu harmiton ja kohtelias käytös ja tasavertaiselta tuntuva vuorovaikutus. Ikävien asioiden ja tunteiden toistuva esiin tuominen on poikkeavaa, jopa epäsuotavaa. Kolmas elämä on Ilka Haarnin sanoin innostusta, elämäniloa, hyvinvointia ja elämänlaatua. Se koostuu mukaan menemisestä, erilaisista osallistumisen rooleista ja tekemisen mahdollisuuksien kirjosta.

Siinä on kadonnut kiire ja työikään liittyvä stressi ja riittämättömyys. Ei siis ihme, että pyrkimykset eläkeikärajan nostamiseksi kahdella vuodella nostattaa vastarintaa.

\section{Anneli Kajanto}

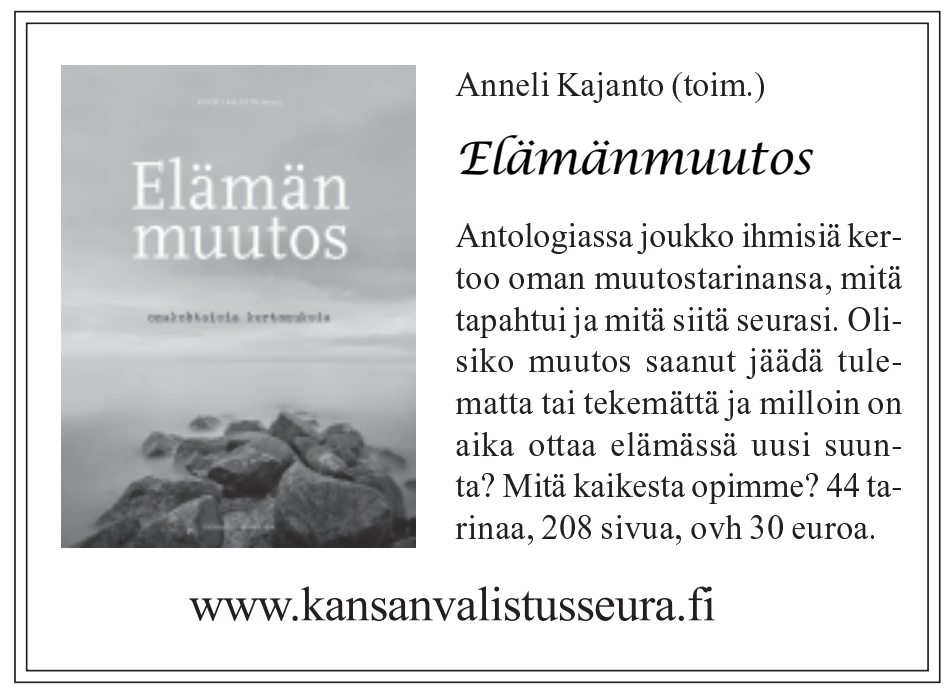

